\title{
Water quality legislation in Palestine over the past century
}

\author{
Amer Marie ${ }^{1}$, Saed Khayat ${ }^{2 *}$ and Muna Dajani
}

\begin{abstract}
Background: This paper deals with the water quality legislation that has been enforced in Palestine over the past century, from the Ottoman era through the British Mandate and Jordanian reign, to the Israeli occupation and current Palestinian autonomy.

Results: The study reveals that, due to the instability and the short interrupted spans of these regimes, apart from the Ottoman era, the successive ruling administrations were unable to draft water legislation in the interest of the Palestinian population, though the more stable Jordanian rule is an exception to this. Moreover, the study shows that the subject of the enacted legislations has depended on the circumstances that the population is subjected to or simply as reaction that deals instantly with a certain problem without taking into account any planning or future socioeconomic development. However, major concerns over the quality of accessible water gained momentum with an ever-increasing demand for limited water resources and the need for water treatment.
\end{abstract}

Conclusions: Investments in legislation and its enforcement will lead to significant economic development and public health and environmental quality enhancement through equitable and reasonable management of shared water resources and community empowerment and awareness.

Keywords: Water quality legislation, Ottoman era, British Mandate, Jordan and Egypt span, Israeli military orders

\section{Background}

Water is the basis for life. Without it, human life would cease; ecosystems would fail and disintegrate. Clean, safe and adequate freshwater is essential for the functioning and viability of ecosystems and communities, and development of society. Historically, water and civilizations have been strongly interlinked. Water has shaped societies and impacted the status of many civilizations [1-3]. In fact, creation or collapse of civilizations is interrelated to availability of water or deterioration of its quality, rendering it unsuitable for agricultural and domestic uses. For example, the Nile has sustained and flourished civilizations on its banks, while Akkadian cultures' collapse more than 4,500 years ago is attributed to the low quality of Tigris River water [4]. The capture of water resources has been the reason why such civilizations and societies have been described as hegemonic and have maintained their existence and survival.

\footnotetext{
* Correspondence: saed.khayat@gmail.com

${ }^{2}$ Technical and Applied Research Centre, Palestine Technical University, Tulkarm 7, Palestine

Full list of author information is available at the end of the article
}

Nomadic communities are constantly moving in search for water and pastureland, both being their source of life. Over centuries, these communities have been consequently unable to build meaningful civilization due to unsustainable usage of water resources in arid area which deteriorated quickly with continuous utilization.

Contamination of natural water resources by agriculture, population growth, industry, urbanization and waste disposal requires proper legislation to contain and safeguard humans and their surrounding environment. With the rapid urbanization of countries worldwide, the need to control the externalities of such urbanization is essential. Much legislation was designed to regulate the water use and water quality aspect with an aim to sustain water resources in terms of quality and quantity, where civilization centers have continued access to the water resources [5].

Since the industrial revolution in the eighteenth century, there has been increased demand on natural resources including water. Conflicts over water resources can occur at multiple levels and scales, whether national (e.g., between farmers and domestic users) or international (between

\section{曾}


countries and entities sharing a water body). Thus, water scarcity can stir up regional conflicts over control of water resources. Where resources become scarce because of natural reasons, including long periods of drought or due to water quality deterioration, such conflicts particularly intensify. Endeavors have, therefore, been made to prevent disputes among such groups and segments. Designing water laws and legislation, ratifying multilateral environmental agreements and enhancing water institutions are among the steps taken to manage shared water resources and ensure sustainable and equitable use of the resources.

These factors have resulted in enactment of water legislations aiming at organizing relations between the different populations in conflict over water resources. Nevertheless, water quality, which is as significant and important as quantity, has been overlooked for decades in terms of legislation, investment and public awareness. Additionally, global data on groundwater quality has been very limited due to the cost of monitoring and analysis; thus, water quality is often neglected in international agreements that deal with shared waters in addition to national legislation [6].

\section{Results and discussion}

\section{Legislation review}

\section{The Ottoman era (mid-nineteenth century-1917)}

The Ottoman Empire was a Turkish empire inspired and sustained by Islam and Islamic institutions. Thus, its legislations relating to water use and preservation were highly influenced by Islamic teachings and laws. The Qur'an asserts that water is the sole basis for the emergence of life: We have made every living thing out of water. (Sura 21, The Prophets, verse 30). The Qur'an also calls for proper governance of water and the equitable sharing of this vital resource:Announce to them how water must be shared among them; each will have his own special time to $\operatorname{drink}$ (Sura 54, The Moon, verse 28). The Ottoman era analyzed, observed and continued the implementation of prevailing legislations and community-adopted norms, i.e., practices recognized in the Palestinian rural areas still in use today that were highly influenced by religious and cultural beliefs.

However, in more urbanized regions (mainly in cities), responsibility for organizing, supplying and safeguarding water resources formed part of the tasks assigned to the Wali (Islamic ruler or governor). The Wali issued decrees in the name of the Ottoman Sultan or his representative rendering such directives binding. This being the case, the water administration can be regarded as centralized and urban-specific. These laws included legislations governing the processes of water disposal and conservation of water, including organizing and bringing drinking and Wudu (ritually pure/ablution) water into urban concentrations.
Distribution of water within the city was the responsibility of 'water carriers' who received instructions given directly by the Wali. The water carriers were in charge of distributing water to cities and entrusted with the task of delivering drinking water to houses and shops in return for a specific fee determined by mutual agreement with the Wali. These water carriers were chosen by an official directly appointed by the Wali. They performed their work in accordance with directives issued by him, defining their working methods and hours [7]. During this period, no clear laws or legislations were issued dealing with drinking water quality. However, stipulation of water's potability and ritual purity was theoretically a sufficient testimony of its good quality. Confirmation of water potability involved both observations made using the various sense (relevant to color, smell and taste) or ascertainment whether water is polluted with materials of visible qualities.

This period was characterized by special measures taken to improve and maintain the quality of water resources. Sabils (public drinking fountains) supplied with water through open or closed ducts for public use (or brought from places of collected rain water) were developed and repaired. This period also witnessed the construction of rain and spring water gathering ponds to be used in summer. An illustrative example of such a pond is Suleiman ponds lying near Al-Khader village to the southwest of Bethlehem. The main objective of constructing these ponds in that area was to collect the water of a number of springs which were particularly abundant with water during winter and spring. The ponds got their name from the Ottoman Sultan Suleiman who ordered them to be built. The springs were chosen because of their conspicuous height of $800 \mathrm{~m}$ above sea level, which is $63 \mathrm{~m}$ higher than the holy Aqsa Mosque of Jerusalem. Thus, water easily flowed to that sanctuary, owing to the difference in altitude, and supplied the mosque with potable and ablution water. These ponds were supervised by officials who were entrusted with their maintenance and protection from pollution. Accordingly, further measures were taken to keep this water source clean. Throwing any dirt around and in the pool, watering livestock there, or doing anything that may cause water quality deterioration was strictly banned.

The Ottoman Empire's keenness on quality water coming to Jerusalem is manifested through the examination of the Contract concluded by and between the Karl-Frank German Firm and Musa Al-Alami, mayor of Jerusalem at that time, for drinking water supply of Jerusalem from the springs of Ein Farah and Fawwar near Hezma Village northeast of Jerusalem. Clause 6 of this contract reads: if water is intended for human consumption it must be lab-tested by the 
Municipality to make sure that it is duly usable for such purpose' [8].

This era also saw both the construction of numerous pools near water springs in villages and assignment of guards to protect these constructions against misuse or pollution of their waters. One typical example is Ein Battir pool in Battir Village northwest of Bethlehem. The dimensions of the pool were $10 \times 10 \mathrm{~m}$ with a depth of $4 \mathrm{~m}$. The spring's water was used for domestic and agricultural consumptions. Parts of the ducts leading to the pool were roofed in order to maintain the quality and quantity of the water. To further conserve this resource and avoid any conflicts among users, the elder of the clan used to distribute the rationed water according to a certain quota. The share of the beneficiary was determined in accordance with the irrigated land area [9]. At the middle of the pool's floor, there was a point which represented the level of the water. A graded scale rod was placed at this point, and each grade was equivalent to a particular share. The water shares of the beneficiaries were distributed over throughout the week. One day, for example, was allotted to one benefiting clan. One of the clan members was assigned on that day to divide water among his clansmen. One and a half shares were allotted for each $20-30-\mathrm{m}^{2}$ plot of irrigated land. The landowner could either directly use the water or store it up in supplementary pools for use on waterless days. This system is still operative in many Palestinian villages (personal interview).

\section{British Mandate period (1917-1948)}

The British Mandate period in Palestine is viewed as a qualitative shift with regard to the enactment of legislation concerning quantitative and qualitative water resources. This legislation was based on scientific, geological and hydrological grounds. A number of plans to design and implement water systems were proposed by researchers who had carried out studies before the British occupation in Palestine. They had envisioned a water situation in Palestine and had attempted to gain a clear idea about both ground and surface waters. Pursuant to recommendations made under these studies, legislation was enacted to deal with surface as well as ground waters.

Other legislation was initiated which provided for the tasks of the agency that managed water resources and the legal procedures governing its work. This legislation included topics not addressed in detail in the past, such as defining areas of surface water drainage, laws that govern them and the agencies responsible for implementation. Laws were also promulgated dealing with pollution and various uses of water like cleaning the sewages and digging of toilet facilities away from municipality area. Other topics addressed included how to deal with water as a commodityit was to be sold in return for a certain price which would be dependent on the water consuming sector. Finally, a penalty fee was initiated for violations of water laws. Sources of laws and legislation during the British Mandate may be confined to the following two levels: (1) the High Commissioner who is the top military and civil functionary representing the British mandatory power, and (2) Local and municipal councils where the first law was enacted by the Bersheba Local Council in 1934.

Laws promulgated by these two levels indirectly dealt with the quality of water through definition of powers entrusted to every agency concerned with water resources. Some important points may be summarized as follows:

1. Restriction of supervision of water installations to municipalities and local councils. Responsibilities of such institutions were confined to conveying water to beneficiaries, collection of dues, doing maintenance work and safeguarding water resources. This is manifested in Article 3 of a law promulgated by the Head of Bni Brak Local Council which provides that, "the Water Administration shall be charged with guard and administration of the water project installations for which it was appointed. It shall also assume responsibility for both the water existent in such installations and the management and supervision of water supply with due observance to the general powers of the Local Council' [10]. This article reflects decentralized distribution of water and leaves municipalities and local councils free to fix the price of water delivered to beneficiaries.

2. The right to supervise water projects including water networks is given to the water department which administratively and financially reports to the municipality, local council or their deputizing agency. This was stated in Articles 4 and 16 of the aforesaid law [11] and in Article 4 of the regulation issued by Al-Bassah Local Council [11]. Here, Article 4 provides that 'the Water Administration or anyone it would assign may, after giving a reasonable notice to the same effect, enter any real property at any time between 8 am and $5 \mathrm{pm}$ to inspect any water pipe that belongs to the Water Administration to repair or remove it' [11]. Thus, responsibility for water network maintenance and removal of illegal connections or stopcocks, if any, was determined pursuant to Article 17 of Al-Bassah Local Council Regulation. It explicitly provided that 'a resident in any real property provided with water shall not waste water through a defected connection or neglectfully leaving a connection or a tap open. 
All damages caused to pipes must be immediately reported to the Water Administration. Pipes, taps and other equipment shall, at the consumer's expense, be repaired or removed by people duly authorized by the Water Administration' [12].

3. The High Commissioner is the source of legislations related to surface water drain according to Article 4 of the Water Drain Law. This Article provides that 'the High Commissioner may declare any area to which this article applies as a water drain area' [12]. Clause 1 of Article 5 of the same Law provides that 'the water supervisor may prevent establishment of any barrier or practice agriculture in any of these areas' [12]. Article 4 of the aforesaid law indicates that a barrier in a watercourse includes any agricultural activity such as any excavations, irrigation ditches or drainage of stream banks and riverbanks. It also includes different aspects causing hygienic hazards or disturbing public peace as this land may be declared as water drain area [12].

4. Public Water Projects Protection Law: Any public water project at any particular area endows it with certain specificity and defines the actions and activities that cannot be exercised within the bounds of such a project. This was stated in Articles 4 and 5 of the Public Water Projects Protection Law. Article 4 provides that 'once a public water project is announced in a certain area, construction of a new well, or changing the dimensions of an already existent one whether in terms of depth or other dimensions, must be done under an additional license given by the District Commissioner'. These protection laws included the farmers' rights. In cases where each farmer had been allocated a particular share of water, such a share was entered in a special register with the Water Department. The use of this water was exclusively restricted to the owner of the land or whoever deputizes for him in its cultivation. It should not be used in any other field or diverted to other lands. This comes under Article 8 of a bylaw issued in accordance with Article 3 of Emergency Powers Decree for 1939 [13].

5. Enactment of legislations which urged for rationalized water consumption. This meant the restriction of water use to allotted fields and recommendation that water's wasteful use be banned for either agricultural or domestic purposes. These laws regarded wastage resulting from water network damage too serious a matter to be postponed. Accordingly, the Water Administration must be immediately notified of the need for repair. Article 17 of Al-Bassah Local Council's Regulations provided that 'A resident in any real property receiving water supply shall not waste water because of a damaged connection or stopcock or leaving open a connection or a tap. Any damage of the equipment must be immediately reported to the Water Administration' [11].

6. Enactment of legislations showing various uses of water. Such water uses were defined and entered into registers. Domestic water use was restricted to prevent its transfer to other purposes such as agriculture or industry. Cases of compulsory uses for other purposes were defined in Article 20 of Bni Brak Local Council Regulations which requires for an additional permit for utilization of domestic water for other purposes like agriculture or industry [10].

7. Construction of any cesspit, lavatory, cesspool or polluted pool near water systems was banned in accordance with Articles 18 and 22 of Bni Brak Local Council Regulations [10]. Bathing humans and animals, and washing clothing in water sources were also banned together with adding any potential pollutants. The same applied to construction of pits, wells, canals or cisterns near a main or subsidiary pipeline of drinking water networks [11].

8. A number of articles in relevant legislations provided for the protection of water resources in agricultural areas. Passage of animals was also regulated across water installations such as pools and canals as provided for in Article 19 of the Surface Water Drain Law No. 15 for year 1942. 'The Water Drain Official may regulate, through banning or any other means, animal or vehicle passage or crossing through special constructions of water drain conduits or their brims or canals' [12].

9. Penal regulations for violators of water laws were initiated. To implement these laws and to fulfill conditions resulting thereof, penalties of imprisonment and/or fine were imposed. Article 21 of the Surface Water Drain Law No. 15 for the year 1942 provided for a penalty not exceeding 1-month imprisonment and/or payment of $10-£$ fine as a maximum [12].

\section{Jordanian rule in the West Bank (1948-1967)}

Relevant laws in force during the British Mandate were not annulled but amended and detailed under Jordanian rule. Clarification of the relation between the supervising authority and the service beneficiaries of the water authority, both farmers and other users, was underlined. Thus, these legislations were formulated in a clearer and more accurate way. To settle all water-related issues, the 'Water Settlement Court' [14] was created with jurisdiction to consider objections to rights to water. The term first appeared in Article 8, Chapter 2 of the Water 
Settlement Law No. 38 for the year 1948 [14]. The Court is comprised of one judge appointed in accordance with the general rules of personnel regulations.

Jordanian laws added several new articles that led to water resources conservation. The Pollution Law was added and defined as any change, which befalls water physical, chemical or biological properties to a degree that actually or potentially reduces its intended usability. Topics addressed by additional Jordanian laws may be summarized as follows:

Agricultural uses Sectors that use water and the rights present on each sector were enumerated. Agricultural uses, for example, were regarded to be a farmer's property rights according to detailed tables in the Water Authority Register which prevents the transfer of allocations to another sector. This was clearly stated in Article 13 of the Water Settlement Law [10]. Article 11 of the Water Control Law provided that, if any agricultural land or part thereof is used for non-agricultural purposes, this particular land forfeits its right to use the water allocated for it and will receive material compensation in return [15]. But if surplus water is available, it will become a state property as provided for in Article 12 of the Water Control Law [15].

Because of its importance at the early days of the Hashemite Kingdom of Jordan, the agricultural sector enjoyed priority in water projects. This was quite natural as over $60 \%$ of the population at the time worked in this sector. Where it was necessary to modify the quantities allocated to any particular sector, this fell under the jurisdiction of the Water Authority director or officer as provided for under Articles 15 and 21 of the Water Settlement Law [14], Article 7 of the Water Control Law and Article 10 of the Water bylaw 'East Ghor Canal Project Draft Law No. 89 for the year 1966. According to this Draft Law, the director general may adjust the water quantities assigned for a certain use as he may deem fit, following a study of the water situation of the area [12]. Prerequisites for planting certain crops were also laid down stipulating preliminary approval before plantation starts. This would help in making planted crops such as bananas, rice, and sugarcane, in addition to pisciculture and perennial fodder plants [16], commensurate with available water quantity as provided for in Article 7 of the Water bylaw East Ghor Canal Project. Accordingly, the supervising agency could adjust the water situation according to the state's priorities, a procedure that virtually placed water consumption under its control.

Industrial uses For water to be used in the industrial sector, Article 27 of the Water Settlement Law provided for obtaining the approval of the Council of Ministers and detailed the allocated quantities and the area of the project (to be attached to the plans) [14]. Moreover, it was stipulated by Article 32 of the Water Settlement Law that the public right shall not be prejudiced in benefiting from water used for drinking and domestic and animal watering purposes [14]. This procedure was confirmed by the provisions of Article 17 of the Water Control Law which provided that permission to use water from any source for industrial or mechanical purposes shall be subject to the approval of the Council of Ministers in consultation with the director where required water exceeds $50 \mathrm{~m}^{3}$ daily [15].

Groundwater New legislation related to groundwater was initiated. Clauses of this legislation emphasized the necessity of obtaining a license from competent authorities for utilization of groundwater. Quantities to be extracted or utilized were duly restricted to any area which had groundwater with a flow of more than $5 \mathrm{~m}^{3}$ / h. By this means, the legislation covered groundwater wells and implicitly excepted small springs [17] as demonstrated by Article 4 of the Groundwater Control Bylaw for the year 1966, which says: 'If groundwater appears with an output of more than $5 \mathrm{~m}^{3} / \mathrm{h}$-while constructing a reservoir or cistern (irrespective of the depth thereof) for water storage, or while making excavation for any purpose whatsoeverthe concerned party must immediately report the same to the deputy director. Failing to do that: the party would be considered as having violated the Law' [18]. Article 6 of the same bylaw openly provides that 'no person may, without license, start or continue extracting groundwater at a daily average of more than $5 \mathrm{~m}^{3}$ /day from one well or two wellswhere the distance separating one another does not exceed fifteen meters. Nor may he do so from any group of wells lying within a land area not exceeding five donums' (one donum equals $1,000 \mathrm{~m}^{2}$.) [18].

Penalties The Project cautiously noticed the necessity of implementation of laws and bringing to account those violating them. Therefore, it created a strict penal system to call to account anyone who partially or totally mishandles or damages water projects irrespective of the cause of damage. Article 35 of the Water Settlement Law provided for the same, explaining that the penalty will be not more than 1-year imprisonment or a fine not exceeding $90 £$, or both [14]. Article 37 of the same law detailed a number of practices and acts that would intentionally or otherwise cause damage to water projects. Within the same context, article 27 of the Water Control Law No. 31 for the year 1953 definitively addressed the topic of violation. The fine was raised to $100 £$ [15]. This manifests that penalties were mainly laid down for safeguarding water projects. 
The following are some legislations dealing with water resource protection in the West Bank until 1967:

1. Defense Regulations No. 6 for the year 1936

2. Municipalities Law No. 29 for the year 1955

3. Penal Code No. 16 for the year 1960

4. Cities, Villages and Buildings Temporary Zoning Law No. 79 for the year 1966.

\section{Egyptian administration: Gaza Strip (1948-1967)}

While the Jordanian government ran the West Bank as a part of the Hashemite Kingdom of Jordan, Egypt administered the affairs of the Gaza Strip including its water resources. Accordingly, the Egyptian government promulgated laws regulating the use of water resources including imposition of special water duties and fees which were detailed in regulations issued by Gaza Municipal Council [18].

Water quality, conservation and rational use were dealt with under Article 19 of the Regulations issued by Rafah Village Council providing as follows: 'Squandering water in any manner and form constitutes a violation of the law.' These regulations urged for the protection of water projects. Clause 2 of Article 20 of the same regulations made illegal the pollution of project water or any utilized water. Clauses 1 and 3 urged for avoidance of mishandling or causing damage to water installations [19].

\section{Israeli occupation period (1967-present)}

From its very beginning, Zionism primarily espoused the idea of seizing land and forging a firm linkage between settlers and such seized land to develop and implant values in the minds of Zionist pioneers, making land the cornerstone of these values. Thus, the embryonic Jewish state in Palestine had a primarily agricultural structure. Zionists viewed water ideologically and were able to demonstrate their power over the Arab inhabitants through several schemes [2].After the 1967 war, Israel declared all water resources in the region (West Bank, Gaza and Israel Proper) as state properties [20]. Since then, Israel has controlled, managed, allocated and sold water to the Palestinian population, paying little heed to the needs of the population it occupies [21].

The outcome of the 1967 war produced what Eran Feitelson identified as a 'hegemonic era' with military superiority effectively preventing the Arab side from challenging Israel's water plans or use [22]. The Israeli occupation of the West Bank territories which are rich in groundwater has led to a series of military orders governing and controlling water use and abstraction, thus, hindering the development of the agricultural sector and complicating the plans to meet the demand of the increasing population in the territories [23]. This consequently led to the issuance of numerous military ordinances since the Israeli occupation of Gaza Strip and the West Bank in June War of 1967. These ordinances served as substitutes for laws and provided easy and smooth control of water resources in the occupied Arab territories after 1967 on which a fait accompli was imposed.

This situation enabled Israel to extract more and more groundwater with impunity while restricting or even banning the land owner from utilization of this source. To perpetuate control over water resources, continued military measures and ordinances were taken and issued under the pretext of safeguarding the quantity and quality of water. The following are the key points addressed by these military ordinances:

The water appropriation right Authority to dispose of water resources was given to the military governor. Ad hoc military ordinances restricted the freedom of water appropriation in particular the water used for agriculture. Military Ordinance No. 498 for the year 1975 issued with regard to water in Gaza Strip says, 'Water extraction, supply or even consumption in the Gaza Strip area is forbidden unless pursuant to a license issued by the Israeli Defense Army' [24]. Clauses (a) and (b) of Article 5 of the Military Ordinance amending the Water Control Law provided for the same effect, adding that it is forbidden to establish any water corporation or any water installations except in accordance with a license given by competent agencies.[25]. Article 24 Clauses (a) and (b) of the Military Ordinance No. 498 for the year 1974 reinforced Israeli control of water resources as it forbids digging groundwater wells without a special permit, which fixes the quantity of water to be used and shows the means to be employed in digging such a well [25].

Thus, it is clear that the early years of Israeli occupation, first and foremost, concentrated on expropriation of the water projects as guaranteed by the Jordanian Law and indirectly vested the military governor with such powers. Secondly, restrictions were imposed on the quantity of extracted water in case a license was given to dig or renovate an artesian well. Rationalized water consumption was another important theme specifically dealt with military ordinances. The interlinkage system was initiated, giving better incentives and more effective consumption of agricultural water. The term 'intermesh' was used in the water ordinance issued in 1980 by the Agricultural Affairs officer [26].

Protection of quality Military ordinances were explicitly and comprehensively issued following the drop in the groundwater aquifer level. These ordinances addressed reducing the water rations given to farmers to 
avoid rising salinity rate. This is particularly clear in the Water Ordinance issued in 1986 by Zakarya Hazan, the Administration officer of Agricultural Affairs in the Gaza Strip. He ordered that water allocations shall be reduced by $10 \%$ regardless of the quantities stated in the extraction licenses issued to farmers [27].

Definition of water pollution The term 'water pollution' was mentioned in Israeli military laws in Article 1 of the Military Ordinance No. 498 for the year 1974. According to this definition, water resource pollution is 'Any change which occurs in the chemical, physiological, bacteriological, radiation, biological or organoleptic properties through adding solid, liquid or gaseous materials to or adjacent to the water source; or extracting the aforesaid materials therefrom, which adversely affects or likely affects water as regards the safety and health of the public, or is likely to adversely affect the animals or plants therein, or makes the water less suitable for the uses it was intended for, regardless of whether the water was used for a particular purpose or it was previously polluted' [25]. According to this definition, pollution is multilateral, multidimensional and is being dealt with on a scientific and legal basis.

Relying on this definition, Article 10 of the same ordinance detailed the actions that may cause water pollution since the article has encompassed industrial and agricultural materials and their effects. In addition, it showed the effect of means of transports near water sources and, finally, the effect of the equipment used in water extraction on water quality. Clause (a) of Article 11 of the same military ordinance also empowered the competent authority to force the local authority to issue regulations forbidding water pollution in its own area [25].

Division of irrigation water Regulations finalized during this period addressed the division of the irrigation system in Jericho area where water was divided into two categories:

1. Horticultural water which is a public property and can be divided according to the land area. Its beneficiary, however, cannot sell, rent or mortgage such water. In case the land is sold, its water allocation will devolve on the new owner. If the land is not cultivated, its water allotment will be held in trust by the government until it is cultivated, but buildings on land will forfeit its share of water [28].

2. Cultivation water which means the water is regarded to be a personal property. Such water is divided as a bequest (in case the first owner dies) to be properly divided between inheritors according to inheritance legislations. Sale of the land does not mean selling this water, but the owner of this water may sell, lease or mortgage the water according to its value and may divert it from one watercourse to another [28].

The Israeli occupation enhanced water management and legislation by registering all wells in the West Bank and Gaza Strip with a code number and a specific quota with a biannual monitoring of these wells. This has created a quantitative database on groundwater quality that is still in use today.

\section{The Palestinian authority period (1996-present)}

The Palestinian Water Authority (PWA) was established following the Oslo interim agreement between Israel and the Palestinian authority (PA). With that, came the establishment of the Joint Water Committee (JWC) compromising of equal numbers of Palestinian and Israeli water experts whose role is to cooperatively manage the West Bank's water and wastewater systems and resources development. Nevertheless, any development water project in the West Bank requires prior approval from the JWC in addition to the approval of the higher authority of the Israeli Civil administration which is an Israeli military body which has been controlling the West Bank since 1967. Therefore, Israel has a veto power and has hindered and constrained the Palestinian proposals for development of water infrastructure projects and even well construction and rehabilitation [20].

The Palestinian water law, enacted on 17 July 2002, aims to develop and manage water resources, increase their capacity, improve their quality and preserve and protect them from pollution and depletion (Article 2). Article 3 of the law clearly stated that water resources in Palestine are a public property.

Clause 2 of Article 5 of the Water Authority Draft Law urged for the development and management of water resources in terms of search and exploration for groundwater. This also includes construction of dams on valleys or development of the existent projects to raise their efficiency. Clause 4 of the same article points out to the necessity of benefiting from the water projects of surface and ground waters, rainwater and desalination of seawater. Clause 5 of the aforesaid article urges for organization and supervision of private and public artesian wells and observation of springs and wellsprings or any other resources. Article 6 of the same aforesaid source restricts the powers of using ground and surface waters and organizes distribution of water in a manner that serves only the interests of the concerned authority in order to curb misuse, wastage or deterioration of the quality of water [29]. Also, Palestinian laws defined pollution in Article 1 of Water Law No. 3 of the year 2002 as any change that occurs to the quality and constituents 
of water which leads to harm to the health of humans and to the environment, therefore, adapting to the previous laws on pollution set forth by the Jordanian and Israeli authorities [30].

Owing to the major importance of water in peace treaties, several clauses have been included in that interim agreement to maintain the good quality of water. This may be summarized as follows:

1. Article 40(3a) mentions the commitment and agreement of both parties to prevent 'the deterioration of water quality in water resources'. Paragraph (e) emphasizes the importance of 'taking all necessary measures to prevent any harm to water resources, including those utilized by the other side'.

2. Maintaining the continuity of currently available water resources in terms of quality and quantity, and owing to the importance of information about water, exchange of hydrological and other information is essential for conservation of water quality.

In essence, Article 40 recognized the water right of the Palestinians in the West Bank and Gaza Strip, while responsibility for managing this water will be transferred to the Palestinian authority. Nevertheless, the level of Israeli control over water resources did not change, and Israel still maintains a strong grip on current water utilization and management in the West Bank [20].

The PWA inherited a system (from the Israeli occupation) with weak infrastructure. With around 160 residential communities without water supply networks and approximately $90 \%$ of these residents without sewage networks, the PWA has had to overcome many challenges to meet the increasing demand for water supply, infrastructure development and sector reform with limited control over resources, weak water institutions and conditional funding. Notwithstanding the short period of time of the establishment and the transfer of limited control of the water resources in the West Bank and Gaza Strip, the PA has undertaken to establish new water policies which reflect the existing water conditions, making the increasing demand on water one of its priorities. These policies include establishment of a water system capable of accommodating the agricultural, population and industrial needs in a manner that enables the PA to address the political challenges and geographical entanglements with Israel [23].

According to the World Bank, the failure to develop wastewater systems in the West Bank and Gaza Strip is the more damaging because water supply quantities and, hence, wastewater quantities have gone up. Additionally, no new sources have been officially developed in Gaza, and acute over drafting of groundwater has led to groundwater quality decline and seawater intrusion [31].
Additionally, Israel has not only failed to support Palestinian attempts to advance solutions for wastewater treatment, it has delayed them. To this day, Israel has not approved Palestinian requests to build wastewater treatment facilities [23]. In addition, untreated waste is being produced by the illegal Jewish settlements in the West Bank.

Nevertheless, the PWA is designing and investing in creating the Palestinian water sector reform plan. This plan developed five strategic goals for the years of 2011-2013, one of which is to provide water sources with adequate quantity and quality in addition to activating systems of monitoring water quality [30].

\section{Comparative review}

This section aims to present a comparative analysis of the pros and cons of the legislation issued during the different regimes by focusing on five aspects that governed the water management sector as shown in Table 1:

In terms of spring water protection and use, it is noted that the Ottoman management mechanisms are still in use today. Ottoman era focused on spring water quality from a societal and religious angle and used it as a rule for water quality protection. The springs have never been regarded as state property but, rather, their ownership was given to the families owning the land where the spring originated from. Thus, it fell on the members of the community to maintain the quality and protection of these water resources. The lack of proper water quality preservation regulations could be explained by the limited water resources at that time where the Ottoman regime itself was dependent on springs as the only water sources available. Accordingly, the efforts were focused on the spring's cleanness and sustainability.

It is noted that the successive governing bodies have also maintained this social mechanism for spring water, but their efforts were more focused on other sources of water, mainly groundwater and new water sources development. The water resources varied during the British Mandate period, reducing concern for the springs' preservation and, consequently, increasing the problems and possibility of springs' pollution. The effects of these problems continue to be felt today.

The best characteristic of the British Mandate period was the linkage between water quality legislation and scientific findings where all the water pollution regulations were based on scientific data. Although most of laws and legislation were meant to assert the British control on water resources and aquifers in Palestine and were also a means of gathering taxes from water usage, the British employed scientific and systematic methods for regulating the relation between the executive power and the water services' beneficiaries. 
Table 1 Comparative analysis of the water governance structure during different administrations

\begin{tabular}{|c|c|c|c|c|c|}
\hline & Legal administration & $\begin{array}{l}\text { Water } \\
\text { resources }\end{array}$ & Community involvement & $\begin{array}{l}\text { Adaptations to } \\
\text { growing knowledge }\end{array}$ & Enforcement mechanisms \\
\hline Ottoman era & $\begin{array}{l}\text { Focus on religious } \\
\text { rulings about water protection }\end{array}$ & Spring water & $\begin{array}{l}\text { Low- } \\
\text { centralized }\end{array}$ & Low & Low \\
\hline \multirow[t]{2}{*}{ British Mandate } & $\begin{array}{l}\text { Linkage between } \\
\text { water quality legislations } \\
\text { and scientific findings }\end{array}$ & $\begin{array}{l}\text { Spring/surface } \\
\text { (limited concern) } \\
\text { and groundwater }\end{array}$ & $\begin{array}{l}\text { High- local authorities } \\
\text { and municipalities }\end{array}$ & High & Penalty system \\
\hline & Wastewater disposal & & & & \\
\hline \multirow[t]{2}{*}{$\begin{array}{l}\text { Jordanian administration } \\
\text { (West Bank) }\end{array}$} & $\begin{array}{l}\text { First definition of } \\
\text { pollution (1955) }\end{array}$ & $\begin{array}{l}\text { Surface water and } \\
\text { groundwater }\end{array}$ & High- decentralization & High & Penalty system \\
\hline & Penalties for violations & & & & \\
\hline $\begin{array}{l}\text { Egyptian administration } \\
\text { (Gaza Strip) }\end{array}$ & Enacted based on previous laws & Groundwater & High- decentralization & & Penalty system \\
\hline \multirow[t]{3}{*}{ Israeli occupation } & Military orders & Groundwater & Highly controlled and centralized & High & Penalty system, military orders \\
\hline & Extension of pollution definition & & & & \\
\hline & $\begin{array}{l}\text { Groundwater wells database } \\
\text { and quotas }\end{array}$ & & & & \\
\hline Palestinian authority & $\begin{array}{l}\text { Developing a legal framework } \\
\text { for water protection } \\
\text { and management }\end{array}$ & Groundwater & High-decentralization & High & Low enforcement of law \\
\hline
\end{tabular}


The local community was given a degree of responsibility for water quality, and the role of decentralization in the decision making relating to water quality control was emphasized. Many approaches and regulations were undertaken by local councils and municipalities, especially in relation to water resource protection which was more flexible than that of the Ottoman era when everything was to be reported back to the Wali. The other main criterion tackled by the British Mandate was the wastewater disposal, in contrast with the Ottoman era which provided less attention to the wastewater issue, its treatment and disposal. The British Mandate has set the rules related to the wastewater disposal systems in the region and issued the appropriate legislation to illustrate the role of wastewater effluent on the deterioration of fresh water quality.

During the Jordanian reign over the West Bank, most of the British water legislation was maintained. The Jordanians continued to use the scientific-based regulations to control the water quality and maintained the decentralization of the role of municipalities and local governments in relation to the water resource protection and control. The first definition of pollution was set by the Jordanians in 1955, and the aspects of water usage, in all sectors, were also identified according to different water quality and aspect of use. The Jordanian period also supported water legislation by setting up a punishment system which instilled in communities a respect for those rules and legislation.

After 1967, when Israel assumed its control over the water resources in the occupied Palestinian territories (OPT), military orders were implemented rather than state legislation. Previous legislations issued during the British Mandate period were kept as it was or modified according to the new situation to fortify the Israeli control over the water resources. One of the main military orders in connection with water quality is the quota system which was implemented to prevent the groundwater deterioration caused by over exploitation. The inhabitants of the OPT suffered from the high demand but low supply of water. It is important to point out that, regardless of the attempts of Israel to control water, the legislation lead indirectly to protect the quantity of groundwater resources in the OPT. The Israeli authority redefined the concept of water pollution by adding to the Jordanian definition of pollutions caused by radiation and organic infection. They also maintained and upgraded the scientific-based laws generated during the British Mandate period. Moreover, they defined the activities that can lead to pollution and connected these activities to the appropriate legislation and punishment regulations.

During the PA period and today, and according to the Oslo Agreement, any changes or modifications in the status quo are not permitted. Therefore, Israeli legislation is still implemented in the OPT. The PWA has to keep using the Israeli legislation accordingly and refer any urgent request related to water to the Joint Water Committee. Current Israeli water policy hinders effective regional solutions to trans-boundary water and wastewater issues [32]. The advantages and disadvantages of each administrative period is summarized in Table 2.

\section{Conclusions}

The prevalence of the interests of the occupying powers over the needs and interests of the Palestinian population is reflected in most of the administrations that have occupied Palestine. The laws, therefore, often contradict the interests of the indigenous people. This is most evident and restricting under the Israeli military occupation. Furthermore, the laws currently in effect are antiquated and out of touch with current socioeconomic development. The burden and responsibility of the PWA is to reform and update the existing laws to reflect the needs of the people and protect the natural environment and resources [21].

From a theoretical as well as applied analysis point of view on water legislation in general and those concerned with water quality in particular, this study has come to the following conclusions: the Palestinian territory is still subject to the regulations and laws of the British Mandate, and there is no actual Palestinian sovereignty which controls and runs natural resources including water resources. The period of the British occupation of Palestine may be seen as a beginning of the promulgation of water legislation which embodied laws for quality protection. Investment and research were focused on developing water plans in the Palestinian cities with a focus on water quotas, taxation and fees collection and disregarding water quality legislation and proper drainage and utilization.

The Jordanian rule in the West Bank and Egyptian administration of the Gaza Strip maintained many of the laws and regulations set by the British, with a focus on water pollution and quality. More efforts were put into development of supply networks to Palestinian cities in addition to investment in the development of the agricultural sector. However, the various water legislation, which preceded the Israeli occupation of the West Bank and Gaza Strip, did not attach due importance to water quality. This was due to several reasons, including giving primary attention to providing the required quantities of water, not to mention the paucity of pollutants during the first half of the twentieth century, a situation completely different from the present time. Finally, competent scientific institutions did not exist at that time to analyze and develop effective water quality monitoring. 
Table 2 Advantages and disadvantages of different administrations of water resources

\begin{tabular}{|c|c|c|}
\hline & Advantages & Disadvantages \\
\hline \multirow[t]{3}{*}{ Ottoman era } & Cities: centralized pure water & Only visual inspection, no scientific-based for water quality \\
\hline & $\begin{array}{l}\text { Villages: distribution and protection } \\
\text { community decision making }\end{array}$ & No enforcement and control over water laws \\
\hline & Water for social purposes & \\
\hline \multirow[t]{7}{*}{ British Mandate } & $\begin{array}{l}\text { Detailed and scientific-based legislation } \\
\text { (geology and hydrogeology) }\end{array}$ & No water laws fully endorsed and implemented \\
\hline & $\begin{array}{l}\text { Linking water with health, } \\
\text { infrastructure development } \\
\text { (strategic thinking and planning) }\end{array}$ & \\
\hline & Penalty & \\
\hline & Pricing & \\
\hline & Water allocation & \\
\hline & Establishing a water law & \\
\hline & Municipality laws & \\
\hline \multirow[t]{2}{*}{ Jordanian administration } & $\begin{array}{l}\text { Adaptation of British water } \\
\text { legislation and amendment (water court) }\end{array}$ & Centralized institution (natural resources authority) \\
\hline & Definition of pollution & No independent water department \\
\hline \multirow[t]{3}{*}{ Israeli occupation } & $\begin{array}{l}\text { Efficient institutional building (central): } \\
\text { support of civil administration }\end{array}$ & $\begin{array}{l}\text { Centralized and militarized institution and control } \\
\text { (linking water department with civil administration } \\
\text { and Mekorot water company) }\end{array}$ \\
\hline & Regulation of quotas & No improvement of water infrastructure \\
\hline & Spring distribution left intact & \\
\hline \multirow[t]{3}{*}{ Palestinian authority } & $\begin{array}{l}\text { First authority to work for the benefit } \\
\text { of the Palestinian people }\end{array}$ & $\begin{array}{l}\text { Laws and articles are characterized as general } \\
\text { and lack proper enforcement mechanisms } \\
\text { and not thoroughly detailed }\end{array}$ \\
\hline & Adaptation of Israeli groundwater quotas & Limited control over the water resources \\
\hline & Maintaining the database system & Degradation of water resources increased \\
\hline
\end{tabular}

Moreover, Israel is held accountable for the pollution of surface and ground waters because of its deliberate neglect of developing the infrastructures in the West Bank as well as in the Gaza Strip throughout its years of occupation. It is necessary to issue water legislation concerned with water quality since overlooking this vital part of legislation could lead to a serious crisis and is economically very costly. Legislation implemented during various periods in Palestine is extremely important for researchers and lawmakers since it will prove useful in the enactment of a Palestinian legislation that conforms to national requirements of economic and sustainable development. The alternative solution in this regard is a better management of binational water wastewater resources that could establish sustainable transboundary resources and sanitation facilities [32].

Re-enhancing the role of the springs as permanent and high quality water resources for drinking purposes, conserving and redeveloping these springs and setting the proper legislation to keep the springs clean is very important. Local communities should be held accountable again with responsibility at a personal and community level. Decentralization in water quality control and distribution of these responsibilities to the local bodies is still needed rather than centralizing the control in the hands of the PWA. The role of the PWA is very important in regulating water utilization and management; however, the distribution of local monitoring and regulatory responsibilities, including legislation for water quality control, should be empowered to the municipalities and local bodies.

The political situation further complicates the current situation related to the water sector. Therefore, the Oslo Interim Agreement's sections on water need to be reconsidered in order to allow for the development of new regulations in Palestine, taking into account previous successful legislation over the last century and the equitable and just distribution of water resources.

Based on the historical development of water quality legislation in Palestine throughout the last hundred years, policy recommendations are as follows:

- Investment into legal research and development of studies and policies on water quality legislation

- To utilize previous advantageous laws and regulations to develop the Palestinian legislation and adjust them to accommodate present and future socioeconomic development policies taking into 
consideration equitable and fair utilization of shared water resources

- Due to the strong linkage between water quality preservation and the community, efforts must be focused on increasing the awareness of communities and empowering local bodies and municipalities to act as guardians of their water resources.

\section{Methods}

Throughout the last century, many unstable regimes have ruled over Palestine, and these successive ruling administrations were unable to draft water legislations in the interest of the Palestinian population. Thus, there was a sequence of legislation that extended or was revised form the Ottoman era. Other laws were newly legislated during the short ruling periods of the different regimes that controlled the area. The history of the legislations related to the water quality in Palestine as well as the modifications of this legislation by the different regimes is reviewed below.

The old legislation beginning from the Ottoman era was collected from previous literature and library archives, especially from the Palestinian Centre for Archive and Culture in Abu-Dis, Jerusalem. British Mandate legislation and Jordanian-Egyptian legislation was found in the archive of Birzeit University at the Institute of Law. The positive and negative impacts throughout these periods were evaluated from the aspects of suitability and validity. Additionally, this paper aims to show some roles that can be reactivated today and the necessity for this reactivation according to the current political and socioeconomic situation.

\section{Competing interests}

No support from any organization for the submitted work; no financial relationships with any organizations that might have an interest in the submitted work in the previous 3 years; no other relationships or activities that could appear to have influenced the submitted work. The authors declare that they have no competing interests.

\section{Authors' contributions}

We alone take full responsibility for the content and analysis herein. AA $M$ and SK collected the whole necessary historical material, analyzed the legislations, and wrote together this analytical study. MD had reviewed the content carefully, including the technical English, and helped in reforming the article. All authors read and approved the final manuscript.

\section{Acknowledgments}

Funding was provided by United States Institute of Peace for a project on 'Water as a Source of Cooperation'. Special thanks for the numinous reviewers for their valuable comments.

\section{Author details}

${ }^{1}$ Environmental Research Lab, Faculty of Science and Technology, Al-Quds University, Beit Hanina, Jerusalem 20002, Palestine. ${ }^{2}$ Technical and Applied Research Centre, Palestine Technical University, Tulkarm 7, Palestine.

\section{Authors' information}

AM is an Associated Professor at Earth and Environmental Sciences Section in Al-Quds University Abu Dees. SK is an Assistant Professor in Technical and
Aplied Research Centre in Palestine Technical University Kadorie. MD is an independent researcher from East Jerusalem, Palestine.

Received: 24 May 2011 Accepted: 27 April 2012

Published: 27 April 2012

\section{References}

1. Movik S: Return of the Leviathan? 'Hydropolitics in the developing world' revisited. Water Policy 2010, 12:1-13.

2. Dinar A, Dinar S, McCaffrey S, McKinney D: Bridges Over Water: Understanding Transboundary Water Conflict, Negotiation and Cooperation. Singapore: World Scientific Publishing Co. Pte. Ltd.; 2007.

3. Wolf A: Shared waters: conflict and cooperation. Annu Rev Environ Resour 2007, 32:241-269.

4. Brooks N: Cultural responses to aridity in the Middle Holocene and increased social complexity. Quat Int 2006, 151(1):29-49.

5. Palaniappan, M., Gleick P. H., Allen L, Cohen MJ, J. Christian-Smith J, and C. Smith C: Clearing the waters: a focus on water quality solutions. N. Ross. (Ed.). In United Nations Environment Programme. Edited by Ross N. UNNairobi: UNON Publishing Services Section; 2010. ISO 14001:2004certified. ISBN: 978-92-807-3074-6.

6. Shumeli D, Shamir U: Application of international law of water quality to recent Middle East water agreements. Water Policy 2001, 3:405-423.

7. Questions of the Wagf in the Ottoman period. Bulletin by Islamic Center for Archive and Cultural Heritage, 2005, Abu Dis Jerusalem.

8. Municipality of Jerusalem: Concession contract between Karl-Frank Company in Germany and the Mayor Al-Alami to provide water to Jerusalem. Translated form Turkish. File No. 44/1052/325/13. 1914

9. Barghouth JM, Al-Sa'ed RMY: Sustainability of ancient water supply facilities in Jerusalem. Sustainability 2009, 1:1106-1119.

10. Bani Brak Local Council: Local Councils Law. Al-Waga'i Al-Filastiniyyah 1947 (a), 1104(002):119.

11. Al-Bassah Local Council: Law of Local Government for the year 1941. Al-Waqa'i Al-Filastiniyyah 1947(b), 1575(002):119.

12. The Palestinian Ministry of Justice: Surface Water Drain Law. No. 15. Al-Waga'i Al-Filastiniyyah 1942, 1204(001):92.

13. The Palestinian Ministry of Justice: Article 3 of the Decree of Emergency Low Defense of Colonies for the year 1939. Al-Waga'i Al-Filastiniyyah 1944, 1373(002):132

14. The Palestinian Ministry of Justice: Water Arbitration Law No. 8. Al-Waga'i al-Filastiniyyah 1946, 880:143

15. The Palestinian Ministry of Justice: Water Monitoring Law No. 31. Al-Waga'i al-Filastiniyyah 1953, 1134(000):163.

16. The Palestinian Ministry of Justice: Water Law for East Ghor Canal Project No. 89. Al-Waga'i al-Filastiniyyah 1966(a), 1943(000):143.

17. The Palestinian Ministry of Justice: Groundwater monitoring Law No. 88. Al-Waga'i al-Filastiniyyah 1966(b), 1943(000):143.

18. Municipal Council of Gaza: Municipalities Law for the year 1934. Al-Waga'i al-Filastiniyyah 1966(c), 0281(000):143.

19. Rafah Village Council: Villages Administration Law No. 23 for the year 1964. Al-Waga'i al-Filastiniyyah 1964, 0241(000):89.

20. Husseini H. The Palestinian Water Authority: developments and challenges involving the legal framework and capacity of the PWA. In Proceedings of the 2nd Israeli-Palestinian International Conference, Water for Life in the Middle East, 10-14 October 2004, 2 vols; Antalya, Turkey. IPCRl; 2004:112-127.

21. Zeitoun M: Power and water in the Middle East: the hidden politics of the Palestinian-Israeli water conflict. New York: L.B.Tauris; 2008.

22. Feitelson $\mathrm{E}$ : The ebb and flow of Arab-Israeli water conflicts: are past confrontations likely to resurface?. Water Policy 2000, 2(4):343-363.

23. Hareuveni E: Foul play: neglect of wastewater treatment in the West Bank. B'Tselem 2009, 1:7-45.

24. Israeli Defense Army: Decree of water (Gaza Strip-No. 498 for the Year 1975). Al-Waga'i al-Filastiniyyah 1982, 0048(000):92.

25. Israeli Defense Army: Ordinance No. 498 concerning water for the year 1974. Al-Waga'i al-Filastiniyyah 1977(a), 0039(000):132

26. Israeli Defense Army: Ordinance concerning water in Gaza Strip No. 498 for the year 1974. Al-Waga'i al-Filastiniyyah 1983, 0053(000):97.

27. Israeli Defense Army: Ordinance concerning water in Gaza Strip No. 498 for the year 1975 and ordinance concerning water (reducing of water quotas for agriculture). Al-Waga'i al-Filastiniyyah 1987, 0079(000):122. 
28. Municipality J: Regulation of irrigation water fees in Jericho area. Jericho Municipality 1977, 1:31-38.

29. Palestinian Water Authority: Internal order No. 66. Al-Waqa'i al-Filastiniyyah 1997, 00018(000):88.

30. Palestinian Water Authority: Water Law No. 3. 2002.

31. World Bank: Assessment of restrictions on Palestinian water sector development Report. Washington: USA; 2009.

32. Al-Sa'ed R: Wastewater issues along the green line, the Israeli-Palestinian border. Int J Environ Stud 2010, 67(6):937-995.

doi:10.1186/2190-4715-24-15

Cite this article as: Marie et al.: Water quality legislation in Palestine

over the past century. Environmental Sciences Europe 2012 24:15.

Submit your manuscript to a SpringerOpen ${ }^{\circ}$ journal and benefit from:

- Convenient online submission

- Rigorous peer review

- Immediate publication on acceptance

- Open access: articles freely available online

- High visibility within the field

- Retaining the copyright to your article

Submit your next manuscript at $\gg$ springeropen.com 